\title{
Molecular characterisation of infectious pancreatic necrosis viruses isolated from farmed fish in Finland
}

\author{
Riikka Holopainen $^{1}$ Anna Maria Eriksson-Kallio ${ }^{2}$ Tuija Gadd $^{1}$
}

Received: 1 April 2017 / Accepted: 20 July 2017 / Published online: 9 August 2017

(C) The Author(s) 2017. This article is an open access publication

\begin{abstract}
Infectious pancreatic necrosis virus (IPNV) has been isolated annually since 1987 from salmonids without clinical signs at coastal fish farms in Finland. In the inland area, viral isolations were rare until 2012, when IPNV was detected at several freshwater fish farms. Between 2013 and 2015, the infection spread and IPNV was continuously isolated from several farms, both inland and on the coast. The aim of this study was to genetically characterise the IPNV isolates collected from Finnish coastal and inland fish farms over the last 15 years, and to detect genetic changes that may have occurred in the virus populations during the study period. The partial VP2 gene sequence from 88 isolates was analysed. In addition, a complete genomic coding sequence was obtained from 11 isolates. Based on the genetic analyses, Finnish IPNV isolates belong to three genogroups: 2,5 and 6 . The genetic properties of the isolates appear to vary between inland farms producing juveniles and food fish farms in the coastal region: the inland farms harboured genogroup 2 isolates, whereas at coastal farms, all three genogroups were detected. Little genetic variation was observed within the Finnish genogroup 2 and 5 isolates, whereas among the genogroup 6 isolates, two subgroups were detected. All isolates studied demonstrated amino acid patterns in the viral VP2 gene previously associated with avirulence. However, increased mortality was
\end{abstract}

Riikka Holopainen

riikka.holopainen@evira.fi

1 Finnish Food Safety Authority Evira, Research and Laboratory Services Department, Virology Research Unit, Mustialankatu 3, 00790 Helsinki, Finland

2 Finnish Food Safety Authority Evira, Research and Laboratory Services Department, Veterinary Bacteriology and Pathology Research Unit, Mustialankatu 3, 00790 Helsinki, Finland detected at some of the farms, indicating that more research is needed to clarify the relationship between the pathogenicity and genetic properties of IPNV isolates from different genogroups.

\section{Introduction}

The genus Aquabirnavirus belongs to the family Birnaviridae, and classifies viruses that have been isolated from various freshwater and marine fish species, as well as from bivalve molluscs and crustaceans [1,2]. Viruses classified within the type species of the genus, Infectious pancreatic necrosis virus cause highly contagious disease and mortality in juvenile salmonid fish [3-5]. The pathogenicity of infectious pancreatic necrosis virus (IPNV) varies greatly, depending not only on the viral isolate, but also on the age and physical condition of the host animal [6-8]. IPNV is distributed worldwide, and the virus is transmitted both vertically and horizontally [2].

Aquabirnavirus particles are non-enveloped and singleshelled with a diameter of about $60 \mathrm{~nm}$ [9]. They have a double-stranded RNA (dsRNA) genome that consists of two linear segments (A and B) [10]. Segment A contains a large open reading frame (ORF) that encodes a 106-kDA polyprotein $\left(\mathrm{NH}_{2}\right.$-pVP2-VP4-VP3-COOH), and a smaller ORF that overlaps the amino-terminal end of the polyprotein ORF that encodes a $17-\mathrm{kDA}$ nonstructural anti-apoptotic protein VP5 [11-13]. The polyprotein is cleaved co-translationally to generate $\mathrm{pVP} 2$, a precursor of the major capsid protein VP2, VP4, a protease, and VP3, a minor capsid protein that forms complexes with the genomic RNA inside the viral capsid. The $\mathrm{pVP} 2$ precursor is further processed to generate a mature VP2 protein [2]. VP2 is the most abundant protein in the virion and is responsible for the production 
of neutralizing antibodies in the host [13]. Additionally, it has been shown in several studies that certain VP2 amino acid residues determine the virulence of IPNV strains, and that some of these amino acid positions are highly variable among different strains $[7,14,15]$. Segment B encodes VP1, an RNA-dependent RNA polymerase (RdRp) that is found free in the viral particle, as well as covalently associated with the viral genome [16]. Aquabirnaviruses have traditionally been classified into nine cross-reactive serotypes, A1-A9, based on their antigenic properties [17]. More recently, viral VP2 gene sequences were shown to correlate with the serological classification and geographical distribution, and genogroups 1-7 were defined based on sequence similarities $[18,19]$.

In the coastal area of Finland, infectious pancreatic necrosis (IPN) was first reported in 1984 [20] and has occurred annually since 1987 on fish farms without causing severe clinical disease. IPNV isolations were extremely rare in continental Finland until 2012, when the virus was detected at several inland farms [21]. The inland IPNV isolates were demonstrated to belong to genogroup 2 based on partial VP2 sequences showing genetic properties associated with low pathogenicity, and the origin of the isolates appeared to be one or several coastal farms.

The aim of this study was to genetically analyse IPN viruses isolated from Finnish fish farms several years before and a few years after the introduction of IPNV in 2012 to inland areas. To achieve this, the partial VP2 gene was sequenced from all isolates studied and a complete coding sequence of the viral genome was obtained from selected isolates using next generation sequencing. The sequences obtained were used to examine the genetic properties of the isolates, including properties associated with pathogenicity, to determine how the IPNV populations have evolved under Finnish fish farming conditions during the past 15 years.

\section{Materials and methods}

\section{Viral isolates}

Altogether, 88 viral isolates were collected from Finnish coastal and inland fish farms during 1989, 2000-2011 and 2014-2015, and analysed for the partial VP2 gene sequence. In addition to VP2 sequences, 11 isolates from the years 1989, 2001, 2007, 2010 and 2012 were analysed for the complete coding region of the genomic segments A and B.

Fish samples from farms located in both the inland freshwater areas of Finland and in the Finnish coastal area of the Baltic Sea were sent to the Finnish Food Safety Authority (Evira) for viral investigation (Fig. 1). The farms included 55 sea cage farms producing food fish or ongrowing juveniles for food fish purposes, or a combination of these, and

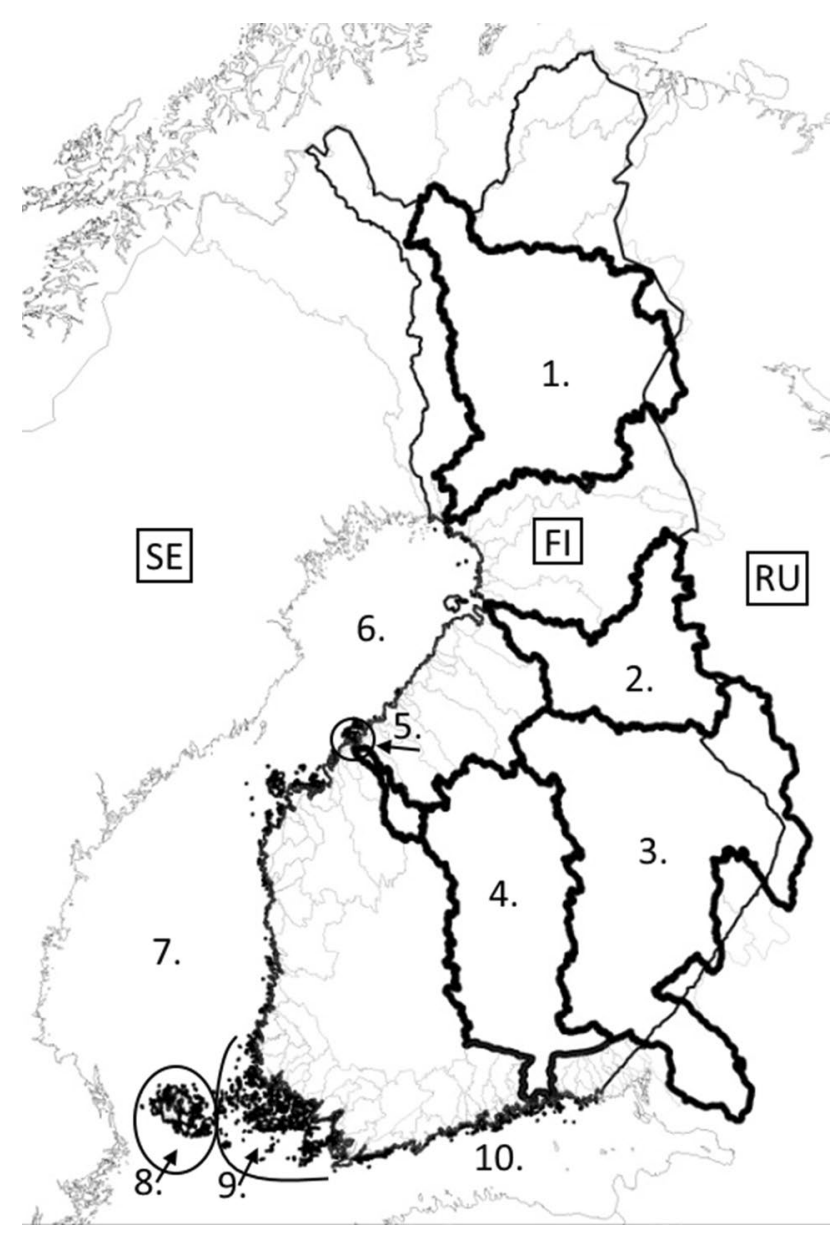

Fig. 1 Map showing the geographical areas from which the viral isolates included in the study were obtained. $1=$ Kemijoki, $2=$ Oulujoki, 3 = Vuoksi, 4 = Kymijoki, 5 = Ähtävänjoki, $6=$ Bothnian Bay, $7=$ Bothnian Sea, $8=$ Alland Islands, freshwater and coastal area, 9 $=$ Archipelago Sea (eastern parts), $10=$ Gulf of Finland. SE $=$ Sweden, $\mathrm{FI}=$ Finland, $\mathrm{RU}=$ Russia

17 freshwater farms, including a hatchery, broodstock fish farms, and farms producing both juveniles and food fish. Most farms were a combination of different types of production systems. In addition, two freshwater recirculation aquaculture system (RAS) farms producing food fish or broodstock fish and juveniles were included. In two cases, the viral isolates originated from wild fish caught for broodstock renewing purposes. The fish were sampled for miscellaneous health screening purposes or the investigation of clinical disease. The fish samples studied consisted of whole fish on ice, live fish, pooled organ samples or ovarian fluids. The whole fish were necropsied, and pooled organ samples consisting of (head or mid-) kidney, spleen and (heart or) brain tissue were used for virus isolation by cell culture. Most of the fish tested were rainbow trout (Oncorhynchus mykiss). However, a few samples were taken from other fish species, namely brown trout (Salmo trutta), Atlantic salmon (Salmo 
salar) and whitefish (Coregonus lavaretus). Viral VP2 gene sequence data for isolates from the period 2012-2014 that were published in our previous work [21] were included in the analyses described here.

\section{Virus isolation in cell culture}

Virus isolations were carried out from pooled organ samples or ovarian fluids. Pooled heart or brain, anterior kidney and spleen tissue from a maximum of 10 fish were homogenised in 9 volumes of cell culture medium (Eagle's MEM, Gibco plus 8 to $10 \%$ foetal bovine serum; $\mathrm{pH} 7.2$ to 7.4 ) containing penicillin and streptomycin. Homogenates were centrifuged $\left(15 \mathrm{~min}, 4000 \times g, 4{ }^{\circ} \mathrm{C}\right)$ and the supernatants inoculated onto subconfluent monolayer cell cultures of bluegill fry (BF-2; [22]) and epithelioma papulosum cyprini (EPC; [23]) cultures in 24-well plates (Nunc A/S) at final dilutions of 1:100 and 1:1000. Before 2009, the samples were incubated at $16{ }^{\circ} \mathrm{C}$ in $\mathrm{CO}_{2}$. After 2009 , the samples were buffered with sodium carbonate $7.5 \%$ (Gibco 25080) and incubated without $\mathrm{CO}_{2}$. The susceptibility of the cell lines to different viruses was tested biannually during the study period by standardised titration procedure. The samples were inspected regularly under a microscope for the occurrence of cytopathic effect (CPE). After $7 \mathrm{~d}$ of incubation, supernatant from samples without CPE was diluted 1:100 and 1:1000, sub-cultured onto fresh cells and incubated for a further 7 d. When CPE was observed, the supernatant was collected and stored at $-70{ }^{\circ} \mathrm{C}$ for future studies.

\section{Detection of viruses with ELISA}

Aliquots of $50 \mu$ l of culture medium from cell cultures showing evidence of CPE were analysed with commercial ELISA kits according to the manufacturer's instructions to test for the presence of IPNV, spring viraemia of carp virus (SVCV), viral haemorrhagic septicaemia virus (VHSV) (Test-Line Ltd., Brno, Czech Republic), and since 2008, also for the presence of infectious hematopoietic necrosis virus (IHNV) (Bio-X Diagnostics S.P.R.L, Jemelle, Belgium).

\section{RNA extraction}

For PCR and subsequent Sanger sequencing, the infected cell culture monolayers were harvested and total RNA was extracted using the QIAamp Viral RNA Mini Kit (Qiagen, Hilden, Germany) according to the manufacturer's instructions. For next generation sequencing, the total RNA was extracted using the RNeasy Mini Kit (Qiagen). During RNA extraction, the RNase-Free DNase Set (Qiagen) was used to remove DNA from the samples.

\section{PCR}

A real-time PCR method with forward primer VP3F: 5'-CGACCGACATGAACAAAATCA-3', reverse primer VP3R: 5'-TGTGCGAATACAGCTGCAACT-3', and VP3 probe: 5'- FAM-TCTAGCCAACAGTGTGTACGGCCT CCC-BHQ1-3, [24]) was used to amplify and detect a 109-base-pair (bp) fragment of the IPNV VP3 gene. The nucleotide (nt) positions of the primers and probe according to a previously published IPNV isolate Sp122 segment A (NCBI GenBank accession number AY354521) were the following: VP3F 5' (2754) - 3' (2774); VP3R 5' (2862) - 3' (2842); VP3 probe 5' (2779) - 3'(2805). Primers F (5'-ACG AACCCCCAGGACAA-3', modified from McColl et al. [25]) and A2 (5'- GACAGGATCATCTTGGCATAGT-3', [26]) were used to amplify 776 bp of the IPNV VP2 gene. The nt positions for the VP2 gene primers according to the IPNV isolate Sp122 segment A were as follows: F 5'(554) -3'(570) and A2 5'(1329) - 3'(1308). For both PCR assays, a one-step reverse transcription (RT)-PCR reaction was performed using the Qiagen OneStep RT-PCR Kit according to the manufacturer's instructions, with $3 \mu \mathrm{l}$ (VP3 real time RT-PCR) and $5 \mu \mathrm{l}$ (VP2 RT-PCR) of RNA as a reaction template.

\section{Sequencing and data analysis}

PCR products were purified from agarose gels using the MinElute Gel Extraction Kit (Qiagen). Both strands of the PCR products were sequenced using the Big Dye Terminator v1.1 Cycle Sequencing Kit (Applied Biosystems, Foster City, CA, USA) and an Applied Biosystems 3130 Genetic Analyzer instrument.

For next generation sequencing (NGS), RNA samples were sent to the Institute for Molecular Medicine Finland (FIMM) in Helsinki, where libraries were prepared and sequenced using an Illumina MiSeq instrument [27], and the raw paired-end sequence data $(2 \times 150 \mathrm{bp})$ were trimmed, followed by de novo analysis for genome assembly using the ABySS assembler [28]. The results of the de novo analyses were further analysed using BLAST to identify the contig sequences containing aquabirnavirus genome sequences. The sequences for genome segments A and B were constructed by compiling the contig sequences using GeneDoc v2.7. Additionally, the trimmed NGS data were assembled by read mapping to reference sequences (GenBank accession numbers for A segment: AY780919, AY354521; B segment: AY780926, AJ622823) using CLC Genomics Workbench 8.5.1. (Qiagen). The sequences for segments A and B obtained from the de novo analyses and from the read mapping to reference sequences were compared and any gaps detected in the sequences were filled by designing specific primers and using Sanger sequencing. 
Phylogenetic analyses for the partial VP2 gene sequences and for the complete coding sequences of $\mathrm{A}$ and B segments were performed with MEGA 7.0.7 [29] using the maximum likelihood method based on the general time-reversible model. The reliability of the analyses was assessed by bootstrap with 1000 replicates. In addition to the other previously published IPNV sequences, the VP2 gene sequences of 85 IPNV isolates from the period 2012-2014 published in a previous study [21] were included in the analyses in order to describe the genetic properties of the Finnish IPNV populations during the whole period from 2000 to 2015 . The GenBank accession numbers for the previously published sequences used were: AF342735 (Jasper), AF343572 (VR299), AF342729 (Ab), AY780919 (6B1A), AF342732 (Canada 1), AF342731 (Tellina virus 2), AF342733 (Canada 2), AF342734 (Canada 3), AJ622822 (Sp 31-75), AJ489229 (88R), AF342730 (Hecht), AY283781 (Y-6) and AY283783 (H1), and for the Finnish IPNV isolates: KR780984 (ka89/12), KR780985 (ka893/12), KR780986 (ka890/12), KR780987 (ka124/12), KR780988 (ka745/12), KR780989 (ka391/13), KR780991 (ka530/13), KR780993 (ka103/14), KR780994 (ka251/14), KR780995 (ka459/14), KR780996 (ka940/14), KR780997 (ka1005/14), KR780998 (ka1049/11), KR780999 (ka568/12), KR781000 (ka844/12), KR781001 (ka692/13), KR781002 (ka735/13), KR781003 (ka764/14), KR781004 (ka954/14), KR781005 (ka978/14), KR781006 (ka1038/14), KR781007 (ka639/12), KR781008 (ka640/12), KR781009 (ka666/12), KR781010 (ka1496/12), KR781011 (ka1613/12) and KR781012 (ka798/13).

The pairwise nucleotide distance of the partial VP gene between all studied isolates and the first inland isolate ka89/12 in 2012 was calculated as the number of nucleotide differences with MEGA. The Kruskal Wallis test was used in multiple group comparisons of nucleotide differences comparing the geographical origin of the isolates, farm type and line of production at the farm. Dunn's test was used for post hoc pairwise multiple comparisons. Statistical analyses were performed with the GraphPad Prism 6 software. Percent similarity values for sequence pairs were calculated using the MegAlign program from the DNASTAR Lasergene 10 application package. Tajima's D test of neutral evolution was conducted with DnaSp 5.10.01 software to detect natural selection in the partial VP2 gene nucleotide sequences. Each dataset tested contained sequences of viruses isolated from the same geographic region in a single year. Because Tajima's D requires at least four sequences for its calculation, data from two consecutive years were combined into one dataset in cases where less than four isolations had been made in a year.

\section{Results}

\section{Virus isolation and identification with ELISA}

IPNV was isolated from 88 pooled samples from rainbow trout, brown trout, whitefish and Atlantic salmon from 10 different geographical areas during 2000-2011 and 2014-2015 (Table 1). In addition, an isolate from 1989 was included in the study, as there was previous knowledge that the isolate belonged to genogroup 6 (Hecht, serotype A4). Altogether, a total of 173 isolates were used in the genetic analyses, including sequences from a previous study [21]. Of these isolates, 155 originated from rainbow trout, 11 from brown trout, 4 from Atlantic salmon, and 3 from whitefish. The annual number of IPNV isolations was relatively low before 2010, with the exception of 2007, when IPNV was isolated from 8 coastal farms. After the introduction of genogroup 2 IPNV into inland farms in 2012, the number of isolations increased and reached the highest level in 2015, with 22 affected farms. Isolates were initially identified by the cytopathic effect, typical of IPNV, which they induced on BF-2 and EPC cells. All isolates studied grew in cell culture, and of these, 71 isolates were positive in the IPNV ELISA test. After conventional PCR and Sanger sequencing, the 11 isolates that were negative in IPNV ELISA were found to be IPNV genogroup 6 isolates. All samples studied were negative for IHNV, SVCV and VHSV in ELISA tests.

\section{PCR and Sanger sequencing of the partial VP2 gene}

The partial VP2 gene was successfully amplified from all 88 isolates using the conventional VP2 RT-PCR with primers $\mathrm{F}$ and $\mathrm{A} 2$. The primer A2 was originally published by Bain et al. [26], and was used to amplify an $1180 \mathrm{bp}$ fragment of the VP2 gene, whereas in this study, a fragment of $767 \mathrm{bp}$ was amplified, sequenced and analysed. Despite the shorter sequences used here, the clustering of isolates of different genogroups remained similar in the phylogenetic analysis, when compared to the results reported by Bain et al. VP2 sequences of a total of 173 Finnish IPNV isolates were used in the genetic analyses, including sequences from a previous study [21]. Based on the phylogenetic analysis (Fig. 2), the Finnish isolates could be categorized into three genogroups; 144 isolates belonged to genogroup 2, 18 isolates to genogroup 5 and 11 isolates to genogroup 6, according to Blake et al. [18] and Nishizawa et al. [19]. The grouping published by Blake et al. was based on a $1611 \mathrm{bp}$ fragment of the VP2 gene, and grouping by Nishizawa et al. was based on a $358 \mathrm{bp}$ fragment of the VP2/NS region. Between 
Table 1 Finnish IPNV isolates from 1989 and 2000-2015

\begin{tabular}{|c|c|c|c|c|c|c|}
\hline $\begin{array}{c}\text { Year of } \\
\text { isolation }\end{array}$ & Geographical area & $\begin{array}{c}\text { No. of } \\
\text { viral } \\
\text { isolates }\end{array}$ & $\begin{array}{c}\text { Line of production } \\
\text { at the farm } \\
\text { (no. of farms) }\end{array}$ & $\begin{array}{l}\text { No. of } \\
\text { affected } \\
\text { farms }\end{array}$ & $\begin{array}{c}\text { Fish } \\
\text { species }\end{array}$ & $\begin{array}{c}\text { Genogroup } \\
\text { (no. of isolates/ } \\
\text { no. of positive farms) }\end{array}$ \\
\hline 1989 & Ähtävänjoki & 1 & $m(1)$ & 1 & BT & $6(1 / 1)$ \\
\hline \multirow[t]{2}{*}{2000} & Archipelago Sea & 2 & $f(1), m(1)$ & 2 & RT & $2(2 / 2)$ \\
\hline & Oulujoki & 1 & $\mathrm{~h}(1)$ & 1 & $\mathrm{~W}$ & $2(1 / 1)$ \\
\hline \multirow[t]{2}{*}{2001} & Gulf of Finland & 1 & $f(1)$ & 1 & RT & $2(1 / 1)$ \\
\hline & Åland Islands & 5 & $f(2), m(1)$ & 3 & RT, AS & $6(3 / 1), 2(2 / 2)$ \\
\hline \multirow[t]{3}{*}{2002} & Archipelago Sea & 1 & $f(1)$ & 1 & RT & $6(1 / 1)$ \\
\hline & Åland Islands & 1 & $f(1)$ & 1 & RT & $2(1 / 1)$ \\
\hline & Ähtävänjoki & 1 & $m(1)$ & 1 & BT & $6(1 / 1)$ \\
\hline \multirow[t]{2}{*}{2003} & Gulf of Finland & 1 & $m(1)$ & 1 & RT & $2(1 / 1)$ \\
\hline & Archipelago Sea & 1 & $m(1)$ & 1 & AS & $2(1 / 1)$ \\
\hline 2004 & Archipelago Sea & 1 & $m(1)$ & 1 & AS & $6(1 / 1)$ \\
\hline \multirow[t]{2}{*}{2005} & Gulf of Finland & 1 & $j(1)$ & 1 & BT & $6(1 / 1)$ \\
\hline & Åland Islands & 2 & $m(1)$ & 1 & $\mathrm{BT}, \mathrm{AS}$ & $2(2 / 1)$ \\
\hline \multirow[t]{2}{*}{2006} & Gulf of Finland & 2 & $f(1)$ & 1 & RT & $2(2 / 1)$ \\
\hline & Åland Islands & 2 & $f(1)$ & 1 & RT & $5(2 / 1)$ \\
\hline \multirow[t]{3}{*}{2007} & Gulf of Finland & 2 & $f(2)$ & 2 & RT & $2(2 / 2)$ \\
\hline & Archipelago Sea & 6 & $f(4)$ & 4 & RT & $2(6 / 4)$ \\
\hline & Åland Islands & 3 & $f(2)$ & 2 & RT & $5(3 / 2)$ \\
\hline 2008 & Bothnian Sea & 1 & $f(1)$ & 1 & RT & $2(1 / 1)$ \\
\hline \multirow[t]{2}{*}{2009} & Archipelago Sea & 5 & $j(1), f(1)$ & 2 & RT & $2(5 / 2)$ \\
\hline & Bothnian Sea & 2 & $f(1)$ & 1 & RT & $2(2 / 1)$ \\
\hline \multirow[t]{3}{*}{2010} & Archipelago Sea & 3 & $m(1), f(1)$ & 2 & RT & $2(3 / 2)$ \\
\hline & Åland Islands & 6 & $f(3), m(1)$ & 4 & $\mathrm{RT}, \mathrm{BT}$ & $2(6 / 4)$ \\
\hline & Bothnian Sea & 1 & $f(1)$ & 1 & RT & $2(1 / 1)$ \\
\hline \multirow[t]{2}{*}{2011} & Archipelago Sea & 1 & $f(1)$ & 1 & $\mathrm{RT}$ & $2(1 / 1)$ \\
\hline & Åland Islands & 8 & $m(1), f(6)$ & 7 & $\mathrm{RT}, \mathrm{BT}$ & $2(3 / 3), 5(5 / 4)$ \\
\hline \multirow[t]{6}{*}{2012} & Gulf of Finland & 1 & $f(1)$ & 1 & RT & $2(1 / 1)$ \\
\hline & Archipelago Sea & 3 & $j(1), f(1)$ & 2 & RT & $2(1 / 1), 5(2 / 1)$ \\
\hline & Åland Islands & 5 & $f(4)$ & 4 & RT & $2(2 / 2), 5(3 / 2)$ \\
\hline & Vuoksi & 4 & $\mathrm{j}(1)$ & 1 & RT & $2(4 / 1)$ \\
\hline & Kymijoki & 14 & $j(1), m(1), f(2)$ & 4 & RT & $2(14 / 4)$ \\
\hline & Kemijoki & 1 & $m(1)$ & 1 & RT & $2(1 / 1)$ \\
\hline \multirow[t]{7}{*}{2013} & Gulf of Finland & 1 & $f(1)$ & 1 & RT & $2(1 / 1)$ \\
\hline & Archipelago Sea & 3 & $j(1), f(1)$ & 2 & RT & $2(3 / 2)$ \\
\hline & Åland Islands & 9 & $f(8)$ & 8 & RT & $2(7 / 7), 5(2 / 1)$ \\
\hline & Bothnian Bay & 1 & $\mathrm{~m}(1)$ & 1 & RT & $2(1 / 1)$ \\
\hline & Vuoksi & 4 & $\mathrm{j}(1), \mathrm{m}(1)$ & 2 & RT & $2(4 / 2)$ \\
\hline & Kymijoki & 12 & $m(2)$ & 2 & RT & $2(12 / 2)$ \\
\hline & Kemijoki & 4 & $m(1), f(1)$ & 2 & RT & $2(4 / 2)$ \\
\hline \multirow[t]{8}{*}{2014} & Gulf of Finland & 2 & $\mathrm{j}(1), \mathrm{m}(1)$ & 2 & $\mathrm{~W}, \mathrm{RT}$ & $2(2 / 2)$ \\
\hline & Archipelago Sea & 2 & $m(1)$ & 1 & $\mathrm{RT}, \mathrm{BT}$ & $6(2 / 1)$ \\
\hline & Åland Islands & 4 & $f(4)$ & 4 & RT & $2(4 / 4)$ \\
\hline & Bothnian Bay & 2 & $f(2)$ & 2 & RT & $2(2 / 2)$ \\
\hline & Bothnian Sea & 1 & $m(1)$ & 1 & RT & $2(1 / 1)$ \\
\hline & Vuoksi & 1 & $m(1)$ & 1 & $\begin{array}{ll}\text { RT } \\
\end{array}$ & $2(1 / 1)$ \\
\hline & Kymijoki & 9 & $f(1), m(2)$ & 3 & $\mathrm{RT}, \mathrm{W}$ & $2(9 / 3)$ \\
\hline & Kemijoki & 2 & $m(1)$ & 1 & RT & $2(2 / 1)$ \\
\hline \multirow[t]{5}{*}{2015} & Archipelago Sea & 7 & $j(1), f(3), m(1)$ & 5 & $\mathrm{BT}, \mathrm{RT}$ & $2(6 / 4), 6(1 / 1)$ \\
\hline & Åland Islands & 8 & $f(5)$ & 5 & RT & $2(7 / 4), 5(1 / 1)$ \\
\hline & Bothnian Sea & 8 & $f(8)$ & 8 & RT & $2(8 / 8)$ \\
\hline & Kymijoki & 1 & $m(1)$ & 1 & RT & $2(1 / 1)$ \\
\hline & Kemijoki & 3 & $j(1), f(1), m(1)$ & 3 & $\mathrm{RT}, \mathrm{BT}$ & $2(3 / 3)$ \\
\hline
\end{tabular}

$\mathrm{f}=$ food fish farm, $\mathrm{m}=$ mixed production producing broodfish, juveniles and/or food fish, $\mathrm{j}=$ juvenile production, $\mathrm{h}=\mathrm{hatchery}$. $\mathrm{RT}=$ rainbow trout Oncorhynchus mykiss, BT = brown trout Salmo trutta, W = whitefish Coregonus lavaretus, AS = Atlantic salmon Salmo salar. Isolates published by Eriksson-Kallio et al. [21] are indicated with grey shading 


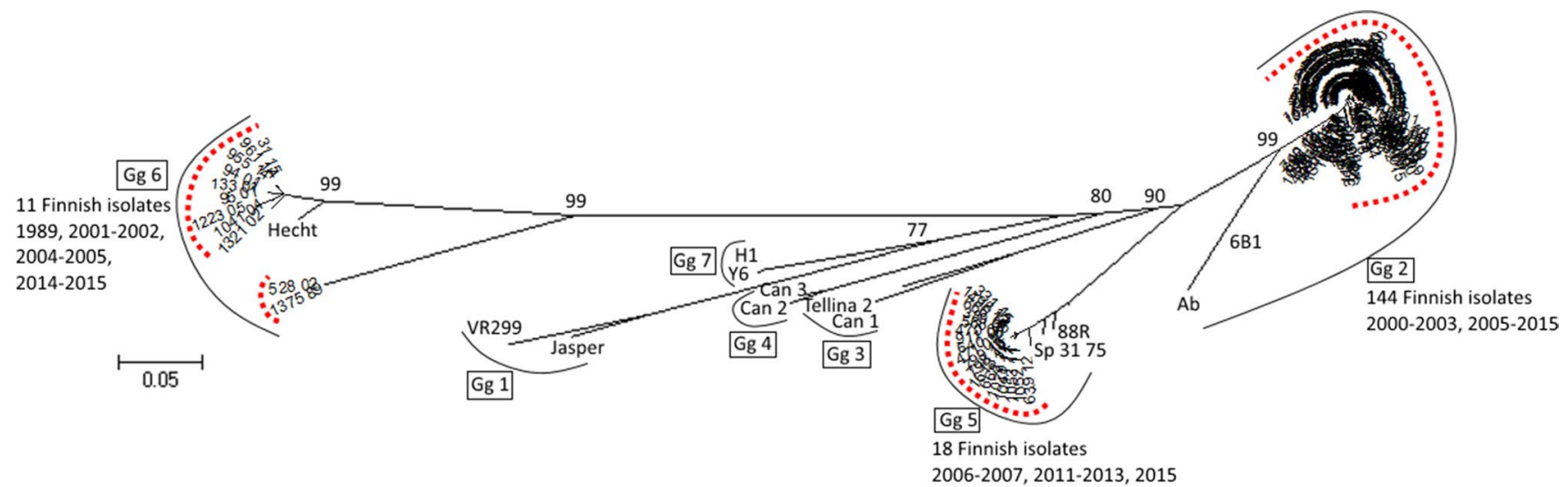

Fig. 2 Maximum likelihood analysis based on partial IPNV VP2 gene sequences. Finnish IPNV isolates are marked with a dotted curved line. Genogroups $(\mathrm{Gg})$ are marked with a solid curved line. The number of isolates and the year of isolation of the Finnish isolates are given under each genogroup. The scale bar indicates the

these two publications there were differences in the grouping of isolates into genogroups 3, 4 and 5. According to Blake et al., isolate Tellina belonged to genogroup 3, isolates Canada 2 and 3 into genogroup 4, and isolate Sp into genogroup 5, whereas according to Nishizawa et al., isolate Tellina belonged to genogroup 4, isolates Canada 2 and 3 into genogroup 5, and isolate $\mathrm{Sp}$ into genogroup 3. In this study, genogroups 3, 4 and 5 were defined as in Blake et al. Altogether 11 isolates were negative in the VP3 real time RT-PCR. All these isolates belonged to genogroup 6 based on the partial VP2 sequences. Based on the polyprotein sequences obtained from the two Finnish genogroup 6 isolates 1379/89 and 94/01, there were 6 nucleotide differences at the annealing site of the primer VP3F in the viral genome compared to the primer sequence. This most likely explains why the VP3 real time RT-PCR was not able to amplify the genogroup 6 isolates.

In the inland area, only genogroup 2 isolates were found, with the exception of two isolations of highly similar genogroup 6 viruses in 1989 and 2002 from the Ähtävänjoki river system. In Ähtävänjoki, the sampling site was situated close to the Bothnian Bay, but several physical barriers hinder the migration of fish. In general, the Finnish isolates appeared to form their own subgroup within genogroup 2. Genogroup 5 isolates formed a more uniform cluster with previously published isolates $\mathrm{Sp}$ 31-75 (GenBank accession number AJ622822) and 88R (GenBank accession number AJ489229), whereas in genogroup 6, two subgroups were revealed. The subgroups consisted of Finnish isolates genetically closely related to the isolate Hecht and more divergent isolates from Ähtävänjoki. Pairwise VP2 gene nucleotide sequence identity values between the Hecht-like and the Ähtävänjoki isolates varied between $80.5-81.4 \%$. In the area of the Aland number of substitutions per site. Numbers at the nodes of the tree indicate bootstrap values; values higher than 70 are given. The GenBank accession numbers of previously published sequences used in the analysis are presented in the "Materials and methods"

Islands and the Archipelago Sea, isolates of all three genogroups were present, whereas in the coastal regions of the Gulf of Finland, genogroup 2 and 6 isolates were found. In the Bothnian Sea and Bothnian Bay regions, only genogroup 2 viruses were isolated. In general, genogroup 2 isolates were the most abundant and they were detected annually throughout the study period, whereas identification of genogroup 5 and 6 isolates was more irregular. Identical genogroup 2 VP2 sequences were detected at the same farm on three different occasions: in two consecutive years both in the Gulf of Finland (2006 and 2007) and Archipelago Sea (2009 and 2010), and in 2013 and 2015 in the Aland Islands. In 2015, an identical isolate was detected in three coastal areas (Åland Islands, Archipelago Sea and Bothnian Bay) at seven separate farms. This isolate type was first detected in the Alland Islands in 2011, after which it was found at several freshwater and coastal farms in 2012-2014 [21].

Recurrent viral infections that occurred during different years on the same farm were detected at several coastal and inland farms. Recurrence was observed with all three IPNV genogroups. Additionally, at some farms, isolates of two different genogroups, either genogroup 2 and 5 or 2 and 6, were detected during the study period.

Genogroup 2 isolates were found in all fish species included in this study, whereas genogroup 5 isolates were only found in rainbow trout and genogroup 6 isolates in rainbow trout, brown trout and Atlantic salmon. Genogroup 2 isolates identical in the VP2 sequence were found in the same year (2000) in whitefish and rainbow trout from two geographically distant locations: Oulujoki and the Archipelago Sea, respectively. The Oulujoki whitefish samples originated from wild brood fish. Similarly, in 2003, genogroup 2 isolates with identical VP2 sequences were found 
Table 2 IPNV isolates that were analysed at the complete polyprotein and VP1 coding region level

\begin{tabular}{|c|c|c|c|c|c|c|c|c|}
\hline \multirow[t]{2}{*}{ Isolate ID } & \multirow[t]{2}{*}{ Origin of the isolate } & \multirow[t]{2}{*}{ Year of isolation } & \multirow[t]{2}{*}{ Fish species } & \multirow[t]{2}{*}{$\begin{array}{l}\text { Passage in } \\
\text { cell culture }\end{array}$} & \multirow[t]{2}{*}{ Genogroup } & \multirow[t]{2}{*}{$\begin{array}{l}\mathrm{G}+\mathrm{C} \text { con- } \\
\text { tent }(\%)\end{array}$} & \multicolumn{2}{|c|}{$\begin{array}{l}\text { GenBank accession } \\
\text { numbers }\end{array}$} \\
\hline & & & & & & & Segment A & Segment B \\
\hline $1375 / 89$ & Ähtävänjoki & 1989 & BT & 6 & 6 & 52.3 & KY548508 & KY548519 \\
\hline $94 / 01$ & Åland Islands & 2001 & AS & 4 & 6 & 52.6 & KY548509 & KY548520 \\
\hline 284/01 & Åland Islands & 2001 & RT & 5 & 2 & 54.7 & KY548510 & KY548521 \\
\hline $470 / 07$ & Åland Islands & 2007 & RT & 2 & 5 & 54.7 & KY548511 & KY548522 \\
\hline $247 / 10$ & Archipelago Sea & 2010 & RT & 4 & 2 & 54.8 & KY548512 & KY548523 \\
\hline $90 / 12$ & Kymijoki & 2012 & RT & 2 & 2 & 55.0 & KY548513 & KY548524 \\
\hline $639 / 12$ & Archipelago Sea & 2012 & RT & 2 & 5 & 54.9 & KY548514 & KY548525 \\
\hline $666 / 12$ & Åland Islands & 2012 & RT & 2 & 5 & 54.7 & KY548515 & KY548526 \\
\hline $745 / 12$ & Kymijoki & 2012 & RT & 2 & 2 & 54.9 & KY548516 & KY548527 \\
\hline $844 / 12$ & Archipelago Sea & 2012 & RT & 3 & 2 & 54.7 & KY548517 & KY548528 \\
\hline $890 / 12$ & Kemijoki & 2012 & $\mathrm{RT}$ & 3 & 2 & 54.9 & KY548518 & KY548529 \\
\hline
\end{tabular}

BT $=$ Brown trout Salmo trutta, AS $=$ Atlantic salmon Salmo salar, $\mathrm{RT}=$ Rainbow trout Oncorhynchus mykiss

in Atlantic salmon and rainbow trout in the Archipelago Sea and the Gulf of Finland, respectively.

Pairwise VP2 gene nucleotide differences between all isolates from the years 1989 and 2000-2015, and the first inland isolate (ka89/12) found in 2012, were calculated as the number of differing nucleotides between two sequences and used in group-wise comparisons of viruses from different geographical origins, and from different farm types and lines of production. Descriptive information on the new and previously published Finnish IPNV isolates is presented in Table 1. The difference in the nucleotide composition of isolates from the Åland Islands and Archipelago Sea compared to the isolates from Kymijoki and Vuoksi was statistically significant ( $p<0.001)$. Moreover, isolates from Vuoksi differed from isolates from Ähtävänjoki and from the Gulf of Finland ( $\mathrm{p}=0.01$ and 0.03 , respectively). When comparing the farm types, the isolates from sea cages differed from freshwater farm isolates ( $\mathrm{p}<0.001)$. Additionally, a difference was observed between isolates from farms producing juveniles and isolates from both food fish farms and farms with mixed production ( $\mathrm{p}=0.007$ and 0.03 , respectively).

Tajima's D values indicating balancing selection or population subdivision were obtained from VP2 gene sequences of Åland Island isolates collected in 2010-2011 (D = 2.06, $\mathrm{p}<0.05)$ and in $2012(\mathrm{D}=1.87, \mathrm{p}<0.05)$. Values indicating purifying selection or rapid population growth were obtained from isolates collected in 2015 from the Aland Islands $(\mathrm{D}=-1.86, \mathrm{p}<0.01)$ and the Archipelago Sea $(\mathrm{D}=-1.75, \mathrm{p}<0.01)$.

Amino acid patterns in the polyprotein suggested to be involved in pathogenicity $[7,14,15]$ were also examined. The most common pattern found in genogroup 2 and 5 isolates was proline at position 217 (Pro217), threonine at position 221 (Thr221) and alanine at position 247 (Ala247).
Additionally, patterns Ser217-Thr221-Ala247 and Pro217Thr221-Gln247 with no reference to pathogenicity in the literature were detected. The latter pattern was only found in genogroup 6 isolates, whereas the former was found in a total of 19 genogroup 2 isolates.

\section{Sequencing of the complete coding regions of viral genome segments $A$ and $B$}

Based on the phylogenetic analysis of the partial VP2 gene sequences, a total of 11 isolates representing genogroups 2, 5 and 6 were chosen for next generation sequencing (Table 2). The coding sequences of the genome segments A and B were obtained from all 11 isolates.

The ORF for the polyprotein in segment A was 2919 bp (973 amino acids) in length in all the studied isolates (Fig. 3). The cleavage sites for the IPNV VP4 protease $\mathrm{N}$ and $\mathrm{C}$ termini were found after amino acids 508 and 734, respectively, as reported previously [30, 31]. Similarly, the cleavage sites within pVP2 were located after amino acid residues 442, 486 and 495. The motifs within pVP2 and at the pVP2-VP4 and VP4-VP3 junction were Ser/Thr - X - Ala $\downarrow$ Ser/Ala - Gly, as described by Petit et al. [32]. The length and positioning of the ORF encoding the VP5 protein in segment A varied between isolates. In genogroup 2 isolates, the length of VP5 ORF was 444 bp (isolates 284/01, $90 / 12,745 / 12,890 / 12$ ) or 429 bp (isolates 247/10, 844/12), whereas in genogroup 5 isolates, the length was 387 bp (isolate 639/12) or $402 \mathrm{bp}$ (isolates 470/07 and 666/12). In all isolates, the VP5 ORF overlapped the polyprotein, but the length of the ORF and the location of the start codon varied between genogroups. The VP5 ORF was not found in the genogroup 6 isolates 1375/89 and 94/01. 


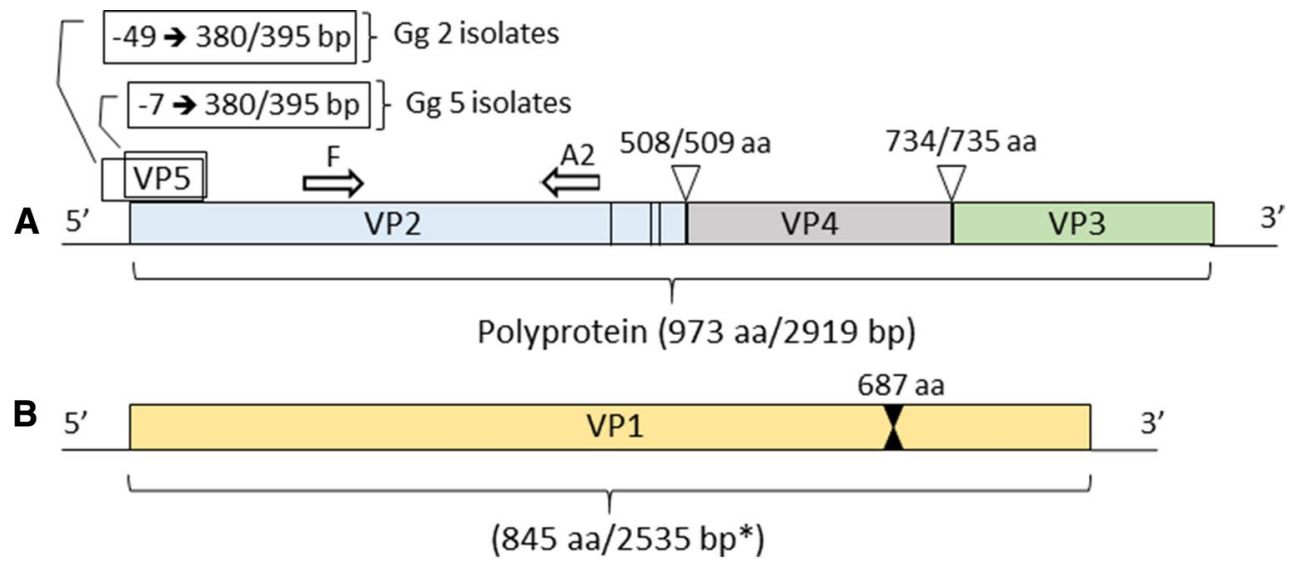

Fig. 3 A and B segments of the Finnish IPNV isolates. The amino acid (aa) positions for the cleavage sites of the polyprotein are marked with arrowheads and vertical lines. The position and length of the VP5 ORF varies between isolates and genogroups $(\mathrm{Gg})$, and is given in nucleotides in relation to the polyprotein ORF. *The length of the
VP1 ORF was 845 aa in all isolates except for $247 / 10$, in which the aa in position 687 was absent. The annealing positions of the primers $F$ and A2 used to amplify a $767 \mathrm{bp}$ fragment of the VP2 are indicated with arrows

as the pairwise sequence identity values of both polyprotein and VP1 sequences (Table 3), confirmed the clustering of isolates. Based on the polyprotein and VP1 sequences, no viral reassortment was detected among the isolates. The
Fig. 4 Maximum likelihood analysis based on IPNV polyprotein sequences. The Finnish isolates are marked with a dotted curved line, and genogroups $(\mathrm{Gg})$ with a solid curved line. The scale bar indicates the number of substitutions per site. Numbers at the nodes of the tree indicate bootstrap values; values higher than 70 are given. The GenBank accession numbers of previously published sequences used in the analysis are presented in the "Materials and methods"

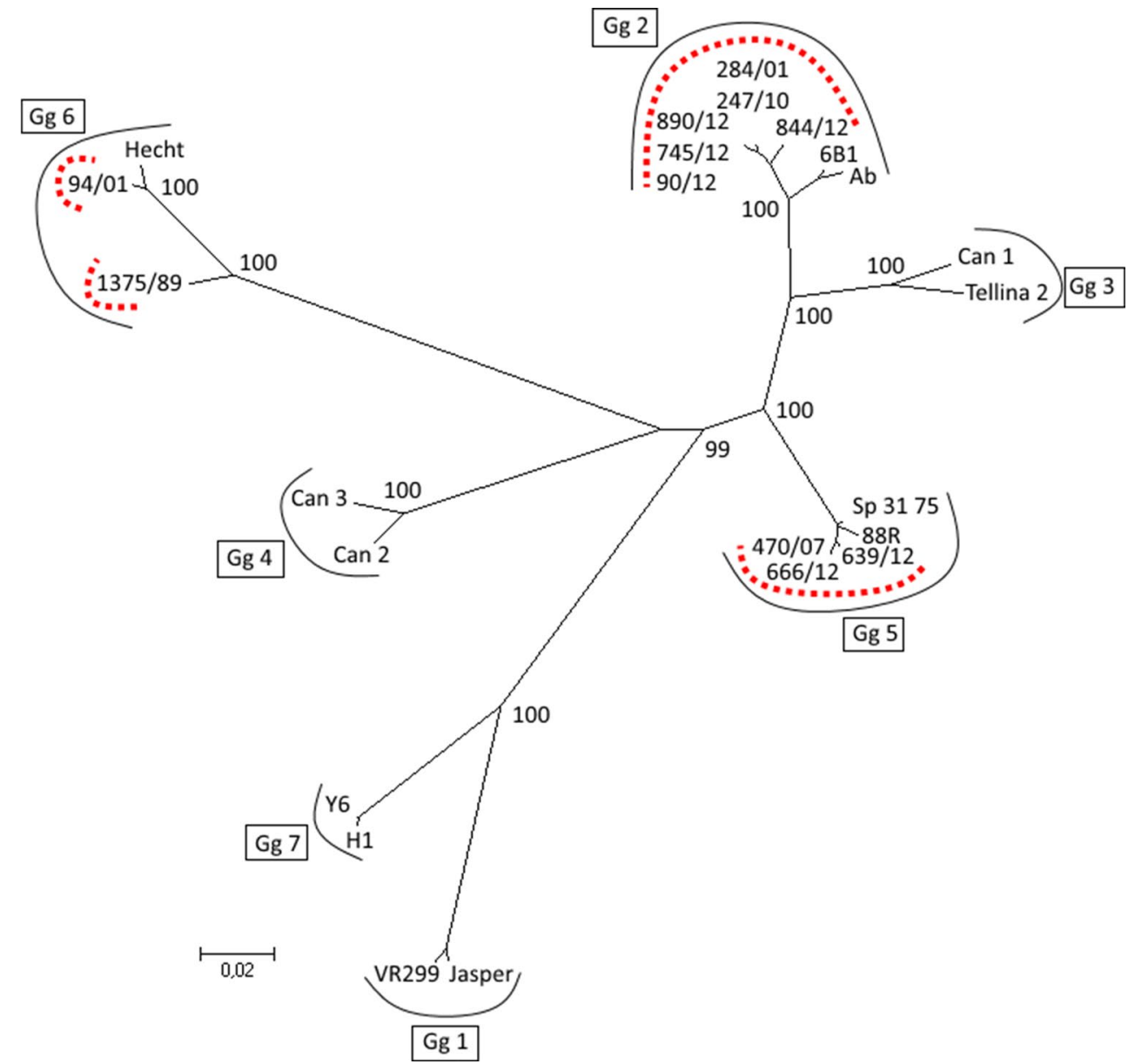


Table 3 Sequence pair similarity values (percentages, \%) based on the nucleotide (nt) and amino acid (aa) sequences of the polyprotein and VP1 coding regions of the IPNV isolates

\begin{tabular}{|c|c|c|c|c|c|c|c|c|c|c|c|c|c|c|}
\hline & \multicolumn{13}{|c|}{ nt } \\
\hline & & \begin{tabular}{|l|} 
Gg 5 \\
Sp 31-75
\end{tabular} & $\begin{array}{l}\text { Gg 2 } \\
6 \mathrm{~B} 1 \\
24 \mathrm{R}\end{array}$ & $\begin{array}{l}\text { Gg 6 } \\
\text { Hecht }\end{array}$ & $1375 / 89$ & $94 / 01$ & $284 / 01$ & $470 / 07$ & $90 / 12$ & $639 / 12$ & $666 / 12$ & $745 / 12$ & $844 / 12$ & $890 / 12$ \\
\hline \multirow{13}{*}{$\mathbf{a a}$} & \begin{tabular}{|l|} 
Gg5 \\
Sp 31-75
\end{tabular} & & $\begin{array}{l}87.7 \\
87.6\end{array}$ & $\begin{array}{l}77.1 \\
79.7\end{array}$ & $\begin{array}{l}78.0 \\
78.2\end{array}$ & $\begin{array}{l}76.7 \\
77.5\end{array}$ & $\begin{array}{l}88.1 \\
88.0\end{array}$ & $\begin{array}{l}98.4 \\
98.1\end{array}$ & $\begin{array}{l}88.2 \\
87.9\end{array}$ & \begin{tabular}{|l|}
98.3 \\
97.8
\end{tabular} & $\begin{array}{l}98.5 \\
98.1\end{array}$ & $\begin{array}{l}88.1 \\
87.8\end{array}$ & $\begin{array}{l}88.1 \\
88.0\end{array}$ & $\begin{array}{l}88.2 \\
87.8\end{array}$ \\
\hline & $\begin{array}{l}\text { Gg2 } \\
6 \mathrm{~B} 1 \\
24 \mathrm{R}\end{array}$ & \begin{tabular}{|l|}
91.4 \\
95.4
\end{tabular} & & $\begin{array}{l}75.7 \\
79.9\end{array}$ & $\begin{array}{l}76.2 \\
78.3\end{array}$ & $\begin{array}{l}75.4 \\
78.4\end{array}$ & $\begin{array}{l}94.0 \\
94.0\end{array}$ & $\begin{array}{l}87.4 \\
87.7\end{array}$ & $\begin{array}{l}94.0 \\
93.8\end{array}$ & $\begin{array}{l}87.4 \\
87.7\end{array}$ & $\begin{array}{l}87.5 \\
87.8\end{array}$ & $\begin{array}{l}94.0 \\
93.8\end{array}$ & \begin{tabular}{|l|}
93.7 \\
93.8
\end{tabular} & $\begin{array}{l}94.0 \\
93.7\end{array}$ \\
\hline & $\begin{array}{l}\text { Gg6 } \\
\text { Hecht }\end{array}$ & $\begin{array}{l}84.9 \\
89.1\end{array}$ & $\begin{array}{l}82.6 \\
87.9\end{array}$ & & $\begin{array}{l}85.1 \\
86.7\end{array}$ & $\begin{array}{l}97.1 \\
89.8\end{array}$ & $\begin{array}{l}76.2 \\
79.1\end{array}$ & $\begin{array}{l}77.1 \\
80.3\end{array}$ & $\begin{array}{l}76.2 \\
79.3\end{array}$ & $\begin{array}{l}77.3 \\
80.5\end{array}$ & $\begin{array}{l}77.0 \\
80.1\end{array}$ & $\begin{array}{l}76.2 \\
79.5\end{array}$ & $\begin{array}{l}76.1 \\
78.9\end{array}$ & $\begin{array}{l}76.2 \\
79.5\end{array}$ \\
\hline & $1375 / 89$ & \begin{tabular}{|l|}
85.7 \\
86.7 \\
\end{tabular} & \begin{tabular}{|l|}
83.6 \\
87.0
\end{tabular} & \begin{tabular}{|l|}
94.9 \\
98.2
\end{tabular} & & $\begin{array}{l}84.9 \\
85.4\end{array}$ & $\begin{array}{l}76.6 \\
78.3 \\
\end{array}$ & $\begin{array}{l}77.7 \\
78.4 \\
\end{array}$ & \begin{tabular}{|l|}
76.8 \\
78.4 \\
\end{tabular} & $\begin{array}{ll}78.1 \\
78.3 \\
\end{array}$ & $\begin{array}{l}77.7 \\
78.4 \\
\end{array}$ & $\begin{array}{l}76.8 \\
78.4 \\
\end{array}$ & $\begin{array}{l}76.7 \\
78.3 \\
\end{array}$ & \begin{tabular}{|l|}
76.7 \\
78.3 \\
\end{tabular} \\
\hline & \begin{tabular}{|c|}
$4 / 01$ \\
\end{tabular} & \begin{tabular}{|l|}
84.9 \\
87.1
\end{tabular} & \begin{tabular}{|l}
82.8 \\
87.6
\end{tabular} & $\begin{array}{l}99.0 \\
99.4\end{array}$ & $\begin{array}{l}95.1 \\
97.2\end{array}$ & & \begin{tabular}{|l|}
75.9 \\
78.2
\end{tabular} & $\begin{array}{l}76.7 \\
77.8\end{array}$ & \begin{tabular}{|l|}
76.0 \\
78.3
\end{tabular} & $\begin{array}{l}77.0 \\
77.7\end{array}$ & $\begin{array}{l}76.6 \\
77.6\end{array}$ & $\begin{array}{l}76.0 \\
78.3\end{array}$ & $\begin{array}{l}75.9 \\
78.6\end{array}$ & $\begin{array}{l}76.0 \\
78.2\end{array}$ \\
\hline & $284 / 01$ & \begin{tabular}{|l|}
91.4 \\
95.1 \\
\end{tabular} & \begin{tabular}{|l|}
97.4 \\
99.3
\end{tabular} & $\begin{array}{l}83.1 \\
87.9\end{array}$ & $\begin{array}{l}83.9 \\
87.1\end{array}$ & $\begin{array}{l}83.2 \\
87.7\end{array}$ & & $\begin{array}{l}87.4 \\
88.1\end{array}$ & $\begin{array}{l}99.2 \\
99.5 \\
\end{array}$ & \begin{tabular}{|l}
87.6 \\
88.1
\end{tabular} & $\begin{array}{l}87.4 \\
88.2\end{array}$ & $\begin{array}{l}99.1 \\
99.6\end{array}$ & \begin{tabular}{|l}
98.3 \\
98.8
\end{tabular} & $\begin{array}{l}99.2 \\
99.4\end{array}$ \\
\hline & $470 / 07$ & \begin{tabular}{|l|}
99.1 \\
99.2
\end{tabular} & $\begin{array}{l}90.7 \\
96.0\end{array}$ & $\begin{array}{l}84.9 \\
88.5\end{array}$ & $\begin{array}{l}85.7 \\
86.8\end{array}$ & $\begin{array}{l}84.9 \\
87.2\end{array}$ & \begin{tabular}{|l|}
90.7 \\
95.7
\end{tabular} & & \begin{tabular}{|l}
87.6 \\
88.0
\end{tabular} & $\begin{array}{l}98.9 \\
99.1\end{array}$ & $\begin{array}{l}99.8 \\
99.7\end{array}$ & $\begin{array}{l}87.5 \\
87.9\end{array}$ & $\begin{array}{l}87.4 \\
88.1\end{array}$ & $\begin{array}{l}87.5 \\
88.0\end{array}$ \\
\hline & $90 / 12$ & \begin{tabular}{|l|}
91.4 \\
95.3
\end{tabular} & \begin{tabular}{|l|}
97.1 \\
99.2
\end{tabular} & $\begin{array}{l}83.2 \\
87.9\end{array}$ & $\begin{array}{l}84.2 \\
87.0\end{array}$ & $\begin{array}{l}83.4 \\
87.6\end{array}$ & \begin{tabular}{|l|}
99.4 \\
99.8
\end{tabular} & $\begin{array}{l}90.7 \\
95.6\end{array}$ & & $\begin{array}{l}87.6 \\
88.0\end{array}$ & $\begin{array}{l}87.6 \\
88.2\end{array}$ & $\begin{array}{l}99.9 \\
99.8\end{array}$ & $\begin{array}{l}98.4 \\
98.6\end{array}$ & $\begin{array}{l}99.9 \\
99.8\end{array}$ \\
\hline & $639 / 12$ & \begin{tabular}{|l|}
99.2 \\
98.8
\end{tabular} & $\begin{array}{l}90.7 \\
95.6\end{array}$ & $\begin{array}{l}84.9 \\
88.5\end{array}$ & $\begin{array}{l}85.7 \\
86.5\end{array}$ & $\begin{array}{l}84.9 \\
86.8\end{array}$ & $\begin{array}{l}90.7 \\
95.4\end{array}$ & $\begin{array}{l}99.5 \\
99.4\end{array}$ & $\begin{array}{l}90.7 \\
95.3\end{array}$ & & $\begin{array}{l}98.8 \\
99.0\end{array}$ & $\begin{array}{l}87.5 \\
88.0\end{array}$ & $\begin{array}{l}87.5 \\
88.1\end{array}$ & $\begin{array}{l}87.5 \\
88.0\end{array}$ \\
\hline & $666 / 12$ & $\begin{array}{l}99.0 \\
99.2\end{array}$ & \begin{tabular}{|l}
90.6 \\
96.0
\end{tabular} & \begin{tabular}{|l|}
84.8 \\
88.5
\end{tabular} & $\begin{array}{l}85.6 \\
86.8\end{array}$ & $\begin{array}{l}84.8 \\
87.2\end{array}$ & \begin{tabular}{|l|}
90.6 \\
95.7
\end{tabular} & $\begin{array}{l}99.9 \\
100.0\end{array}$ & \begin{tabular}{|l|}
90.6 \\
95.6
\end{tabular} & $\begin{array}{l}99.4 \\
99.4\end{array}$ & & $\begin{array}{l}87.5 \\
88.1\end{array}$ & $\begin{array}{l}87.5 \\
88.2\end{array}$ & $\begin{array}{l}87.5 \\
88.1\end{array}$ \\
\hline & $745 / 12$ & $\begin{array}{l}91.4 \\
95.1\end{array}$ & \begin{tabular}{|l}
97.2 \\
99.3
\end{tabular} & $\begin{array}{l}83.4 \\
87.9\end{array}$ & $\begin{array}{l}84.3 \\
87.1\end{array}$ & $\begin{array}{l}83.5 \\
87.7\end{array}$ & \begin{tabular}{|l|}
99.5 \\
99.9
\end{tabular} & $\begin{array}{l}90.7 \\
95.7\end{array}$ & \begin{tabular}{|l|}
99.9 \\
99.9
\end{tabular} & $\begin{array}{l}90.7 \\
95.4\end{array}$ & $\begin{array}{l}90.6 \\
95.7\end{array}$ & & $\begin{array}{l}98.4 \\
98.6\end{array}$ & $\begin{array}{l}99.9 \\
99.8\end{array}$ \\
\hline & $844 / 12$ & $\begin{array}{l}91.3 \\
95.1\end{array}$ & $\begin{array}{l}97.0 \\
99.3\end{array}$ & $\begin{array}{l}83.0 \\
87.3\end{array}$ & $\begin{array}{l}83.8 \\
87.1\end{array}$ & $\begin{array}{l}83.4 \\
87.7\end{array}$ & $\begin{array}{l}98.9 \\
99.8\end{array}$ & $\begin{array}{l}90.6 \\
95.7\end{array}$ & \begin{tabular}{|l}
98.7 \\
99.6
\end{tabular} & $\begin{array}{l}90.6 \\
95.4\end{array}$ & $\begin{array}{l}90.5 \\
95.7\end{array}$ & $\begin{array}{l}98.8 \\
99.8\end{array}$ & & $\begin{array}{l}98.4 \\
98.5\end{array}$ \\
\hline & $890 / 12$ & $\begin{array}{l}91.4 \\
95.3\end{array}$ & $\begin{array}{l}97.2 \\
99.2\end{array}$ & \begin{tabular}{|l|}
83.4 \\
87.9
\end{tabular} & $\begin{array}{l}84.3 \\
87.1\end{array}$ & $\begin{array}{l}83.5 \\
87.7\end{array}$ & \begin{tabular}{|l|}
99.5 \\
99.8
\end{tabular} & \begin{tabular}{|l|}
90.7 \\
95.9
\end{tabular} & \begin{tabular}{|l|}
99.9 \\
99.8
\end{tabular} & $\begin{array}{l}90.7 \\
95.5\end{array}$ & $\begin{array}{l}90.6 \\
95.9\end{array}$ & $\begin{array}{l}100.0 \\
99.9\end{array}$ & $\begin{array}{l}98.8 \\
99.6\end{array}$ & \\
\hline
\end{tabular}

Nucleotide sequence identity values are presented in the upper diagonal, and amino acid sequence identity values in the lower diagonal part of the table. In each cell, the upper value is for the polyprotein and the lower value is for the VP1 sequences. NCBI Genbank Accession numbers for previously published polyprotein sequences: Sp 31-75 (AJ622822), 6B1 (AY780919), Hecht (AF342730), and for the VP1 sequences: Sp 31-75 (AJ622823), 24R (AJ489243), Hecht (JF734351, partial VP1 sequence: 498bp). The highest similarity values for each Finnish IPNV isolate are in bold. $\mathrm{Gg}=$ genogroup

overall sequence pair similarity among Finnish genogroup 2 isolates varied between $98.3 \%$ and $99.9 \%$ at the nucleotide level and $98.7 \%$ and $100 \%$ at the amino acid level for the polyprotein and VP1 gene, respectively. Among genogroup 5 isolates, the similarity values for nucleotide sequences were 98.8\% to $99.7 \%$ and for the amino acid sequences $99.5 \%$ to $100 \%$. Between the two genogroup 6 isolates 1375/89 and $94 / 01$, higher genetic diversity was detected, with nucleotide sequence similarity values of $84.9 \%$ and $85.4 \%$ for the polyprotein and VP1, respectively. These results supported the subgrouping of the genogroup 6 isolates that was detected based on VP2 sequences.

The VP1 ORF in segment B was 2535 bp in all isolates except for isolate $247 / 10$, in which the coding region was 2532 bp. Only a partial VP1 sequence of genogroup 6 IPNV (isolate Hecht) was available in the NCBI GenBank for genetic analysis and sequence comparisons. Based on both polyprotein and VP1 sequences, isolate 94/01 showed high similarity with isolate Hecht, whereas isolate 1375/89 appeared to be more divergent at both the nucleotide and amino acid sequence level.

The overall $\mathrm{G}+\mathrm{C}$ content of the coding genomic regions of the isolates studied varied between $52.3 \%$ and $55 \%$; the genogroup 6 isolates 1375/89 and 94/01 exhibited a lower $\mathrm{G}+\mathrm{C}$ content than the genogroup 2 and 5 isolates.

\section{Discussion}

As a continuation of our previous research focusing on the period from 2012-2014 [21], this study describes the molecular analysis of IPNV isolates collected from Finnish fish farms during 2000-2011 and 2015. Based on the genetic analyses, IPNV genogroups 2, 5 and 6 were present at the fish farms during the study period. In general, the genetic diversity within the Finnish genogroups 2 and 5 was relatively low, whereas within genogroup 6 , two subgroups were revealed. Based on the polyprotein and VP1 sequences, the 
genetic distance between genogroup 6 isolates and genogroup 2 and 5 isolates appeared to be relatively high. This was most likely the reason why the genogroup 6 isolates were not detected with ELISA or with the VP3 real time RT-PCR used in this study as these methods were developed mainly for the detection of genogroup 5 IPNV. Genogroup 2 isolates were the most abundant at both the inland and coastal farms. Genogroup 6 occurred sporadically, and was generally isolated from farms taking in fish material originating from wild fish.

The main cultured food fish species in Finland [33], and therefore the most common species sent for viral sampling to Evira, is rainbow trout. Thus, 154 of the 173 IPNV isolates collected during 2000-2015 originated from rainbow trout. Genogroup 2 and 6 IPNV isolates were found in several salmonid fish species, whereas genogroup 5 isolates were only found in rainbow trout. In addition to genogroup 2, only two isolations of genogroup 6 viruses in the Ähtävänjoki river system close to the coast of Bothnian Bay were made from the inland farms. At the coastal farms of the Åland Islands and Archipelago Sea, isolates of all three genogroups were found.

Besides the geographic origin, the farm type and line of production appear to have a relationship with the genetic properties of the isolates present at the farm. In general, Finnish fish production is divided into two geographical areas: the production of broodstock and juveniles in freshwater inland farms, and the production of food fish at brackish water coastal farms, with some minor exceptions. In Finland, the majority of rainbow trout originate from domestic broodfish. From the end of 1980s to 1998, import of live fish and eggs to Finland was forbidden, and since 1998, only fish and eggs from IPN-free sources have been allowed to be imported. The IPNV isolates found at the broodstock and juvenile farms seemed to differ genetically from the food fish farm isolates. As described previously [21], the source of genogroup 2 IPNV introduced to inland farms in 2012 was most likely one or several coastal farms. The genogroup 2 isolate type that was first detected in the Alland Islands in 2011 was later found at several inland and coastal farms in 2012-2015. The annual number of IPNV isolations in the coastal farms increased after the introduction of genogroup 2 IPNV to the inland farms. This can most likely be explained by the transfer of juvenile fish from inland farms to food fish farms in the coastal area. The results obtained from Tajima's D test in this study support the theory of an increased viral population size in the coastal area of the Åland Islands and Archipelago Sea in 2015. Most of the viral isolates in this study were obtained from the Åland Islands and Archipelago Sea, reflecting the fact that the majority of food fish farms are located in this area. In addition, the mixing of fish from different sources is common, enabling the spread of viral isolates between farms. However, in order to prevent the spread of genogroup 5 isolates to inland areas, the transfer of fish from coastal areas to inland is restricted by legislation.

In this study, complete genomic coding sequence was obtained from 11 isolates from all three IPNV genogroups observed. Prior to this study, only partial VP1 sequences of genogroup 6 IPNV were available in the NCBI GenBank. The phylogenetic clustering based on complete coding sequences of genomic segments A and B of Finnish IPNV isolates was in accordance with the results obtained from VP2 gene sequences. This indicates that no genetic reassortants were among the isolates studied although fish from different sources are often mixed. Reassortment is an important mechanism of evolution in dsRNA viruses [34], and natural reassortment has been shown to occur in IPNV [35]. The isolates studied here showed variance in the length and positioning of the VP5 ORF in genomic segment A. In general, the genogroup 5 isolates exhibited shorter VP5 ORFs than the genogroup 2 isolates, whereas in the genogroup 6 isolates, no VP5 ORF was found. The absence of VP5 in genogroup 6 isolate Hecht has previously been reported [36]. Additionally, it has been shown that VP5 is not needed for viral replication, and that its absence does not affect the virulence of the virus or the establishment of persistent IPNV infection $[37,38]$.

The association of certain amino acid patterns in the viral polyprotein and virulence of genogroup 5 (serotype Sp) IPNV isolates has been described in several publications $[14,15,39]$. As shown previously with the Finnish IPNV isolates from 2012-2014 [21], most of the genogroup 2 and 5 isolates in this study demonstrated the amino acid pattern Pro217-Thr221-Ala247. In Scotland and Ireland, the same amino acid pattern has been detected in genogroup 5 isolates in connection with clinical outbreaks [26, 40], whereas in Norway, the pattern has been associated with avirulence [41] or subclinical disease [39]. All genogroup 6 isolates in this study exhibited amino acids Pro217-Thr221-Gln247, a pattern that has neither been connected with virulence nor avirulence in the literature. No severe IPN outbreaks have so far occurred in Finland. However, increased mortality rates in coinfections with IPNV and bacterial diseases have been noted frequently [21]. In addition, mortalities of susceptible fry showing histopathological findings consistent with IPN with no association with other infectious agents than IPNV have been reported. Apart from reports of genogroup 1 IPNV from Chile $[42,43]$, where the isolates from clinical outbreaks had the amino acid pattern Ala217-Thr221, little information is available on the virulence-related aminoacid motifs of IPNV genogroups other than genogroup 5 . Virulence and mortality depends not only on the genetic properties of the virus, but also on factors related to the host immune system [44]. Fish are believed to develop resistance to IPNV infection with age [45]. Ortega et al. [43] reported that the genotype and the infectivity of different 
IPNV isolates does not translate into clear differences in the antiviral responses in the host. Additionally, it has been shown that in persistently infected salmon, environmental stress can lead to changes where attenuated, nonvirulent IPNV variants become more virulent [46]. It is evident that experimental infection trials are needed in order to obtain more information on the genetic properties related to the virulence of isolates of different IPNV genogroups.

Fish surviving IPNV infection become asymptomatic persistent carriers of the virus [47], and carrier fish are very common [48]. Both virulent and avirulent IPNV isolates are able to establish persistent infection [49]. In carrier fish, IPNV has been reported to reside and multiply within head kidney-derived leukocytes [50, 51]. It has been suggested that IPNV infects B lymphocytes and causes immunosuppression, resulting in a carrier state [52], and that the viruses attenuate the antiviral responses in the host at different levels which may cause differences in the disease outcome [49]. Additionally, it has been shown that in the carrier state, the virus titre can vary with time from non-detectable to comparatively high [53-55]. Here, the two highly similar genogroup 6 isolates found in brown trout in Ähtävänjoki in 1989 and 2002 indicate that the virus is able to remain on the same farm for years. Wild fish carriers of IPNV cannot be ruled out as a source of infection because of the lack of systematic, targeted surveys on the occurrence of IPNV in wild fish in Finnish waters. However, wild salmonid broodfish and other wild salmonids sent to Evira, both from the sea area and the inland area, are tested annually for IPNV, and no IPNV has been found in inland waters [21]. It has been show that IPNV can be isolated from mussels, sediment and surface water in the vicinity of clinically infected farms [56]. However, there is little information on whether IPNV released from environmental reservoirs could re-infect or sustain infection on fish farms. As shown in this study, IPNV appears to be widely spread among Finnish fish farms, and the number of annual viral isolations has recently increased. It has been shown that the prevalence of IPNV can differ between years [57]. On the other hand, the prevalence at marine sites may be underestimated and the virus could be ubiquitous [58]. In this study, the recurrence of viral infection at the same farm was detected in several coastal and inland farms, indicating either persistent infection or reinfection. In the inland broodstock and juvenile production farms, the infection is most likely sustained in fish that can be held at the same location for longer periods of time. In the coastal food fish farms, the fish material is regularly replaced, and recurring infections most likely originate from incoming fish stock or from the environment.

In conclusion, IPNV appears to be a highly prevalent pathogen on Finnish fish farms, and genogroup 2 is geographically more widely spread than genogroups 5 or 6 . In coastal food fish farms, all three genogroups were found, whereas in the inland broodstock and juvenile producing farms, only genogroup 2 was regularly detected. Genogroups 2 and 5 appear to be genetically more uniform than genogroup 6. All isolates studied here demonstrated amino acid patterns previously associated with avirulence in genogroup 5. However, more research is needed to clarify the relationship between pathogenicity and genetic properties of different IPNV genogroups.

Acknowledgements We gratefully acknowledge Hanna Kuukka-Anttila for map design and for gathering information on the farms, Satu Viljamaa-Dirks for critical comments on the manuscript, Katri Leino and Hanna Kauno for technical assistance, and the Finnish Foundation of Veterinary Research for financial support.

\section{Compliance with ethical standards}

Funding This study was funded by the Finnish Foundation of Veterinary Research.

Conflict of interest The authors declare that they have no conflict of interest.

Ethical approval This article does not contain any studies with animals performed by any of the authors.

Open Access This article is distributed under the terms of the Creative Commons Attribution 4.0 International License (http://creativecommons.org/licenses/by/4.0/), which permits unrestricted use, distribution, and reproduction in any medium, provided you give appropriate credit to the original author(s) and the source, provide a link to the Creative Commons license, and indicate if changes were made.

\section{References}

1. Rodriguez Saint-Jean S, Borrego JJ, Perez-Prieto SI (2003) Infectious pancreatic necrosis virus: biology, pathogenesis, and diagnostic methods. Adv Virus Res 62:113-165

2. Delmas B, Mundt E, Vakharia VN, Wu JL (2012) Family Birnaviridae. In: King AMQ, Adams MJ, Carstens EB, Lefkowitz EJ (eds) Virus taxonomy: Classification and Nomenclature of Viruses Ninth Report of the International Committee on Taxonomy of Viruses. Elsevier Academic Press, San Diego

3. Wolf K (1988) Fish viruses and fish viral diseases. Canstock Publishing Associates, Cornell University Press, Ithaca

4. Jarp J, Gjevre AG, Olsen AB, Bruheim T (1994) Risk factors for furunculosis, infectious pancreatic necrosis and mortality in post-smolt of Atlantic salmon, Salmo salar L. J Fish Dis 18:67-78

5. Taksdal T, Stangeland K, Dannevig BH (1997) Induction of infectious pancreatic necrosis (IPN) in Atlantic salmon Salmo salar and brook trout Salvelinus fontinalis by bath challenge of fry with infectious pancreatic necrosis virus (IPNV) serotype Sp. Dis Aquat Org 28:39-44

6. Taksdal T, Ramstad A, Stangeland K, Dannevig BH (1998) Induction of infectious pancreatic necrosis (IPN) in covertly infected Atlantic salmon, Salmo salar L., post-smolts by stress exposure, by injection of IPN virus (IPNV) and by cohabitation. J Fish Dis 21:193-204 
7. Bruslind LD, Reno PW (2000) Virulence comparison of three Buhl-subtype isolates of infectious pancreatic necrosis viruses in brook trout fry. J Aquat Anim Health 12:301-315

8. Houston RD, Haley CS, Hamilton A, Guy DR, Mota-Velasco JC, Gheyas AA, Tinch AE, Taggart JB, Bron JE, Starkey WG, McAndrew BJ, Verner-Jeffreys DW, Paley RK, Rimmer GS, Tew IJ, Bishop SC (2010) The susceptibility of Atlantic salmon fry to freshwater infectious pancreatic necrosis is largely explained by a major QTL. Heredity (Edinb) 105:318-327

9. Dobos P (1995) The molecular biology of infectious pancreatic necrosis virus (IPNV). Ann Rev Fish Dis 5:25-54

10. Dobos P (1976) Size and structure of the genome of infectious pancreatic necrosis virus. Nucleic Acids Res 3:1903-1924

11. Dobos P (1977) Virus-specific protein synthesis in cells infected by infectious pancreatic necrosis virus. J Virol 21:242-258

12. Duncan R, Nagy E, Krell PJ, Dobos P (1987) Synthesis of the infectious pancreatic necrosis virus polyprotein, detection of a virus-encoded protease, and fine structure mapping of genome segment A coding regions. J Virol 61:3655-3664

13. Magyar G, Dobos P (1994) Evidence for the detection of the infectious pancreatic necrosis virus polyprotein and the $17-\mathrm{kDa}$ polypeptide in infected cells and of the NS protease in purified virus. Virology 204:580-589

14. Santi N, Vakharia VN, Evensen $\varnothing$ (2004) Identification of putative motifs involved in the virulence of infectious pancreatic necrosis virus. Virology 322:31-40

15. Shivappa RB, Song H, Yao K, Aas-Eng A, Evensen O, Vakharia VN (2004) Molecular characterization of Sp serotype strains of infectious pancreatic necrosis virus exhibiting differences in virulence. Dis Aquat Organ 61:23-32

16. Duncan R, Mason CL, Nagy E, Leong JA, Dobos P (1991) Sequence analysis of infectious pancreatic necrosis virus genome segment B and its encoded VP1 protein: a putative RNA-dependent RNA polymerase lacking the Gly-Asp-Asp motif. Virology 181:541-552

17. Hill B, Way K (1995) Serological classification of infectious pancreatic necrosis (IPN) virus and other aquabirna viruses. Ann Rev Fish Dis 5:55-77

18. Blake S, Ma JY, Caporale DA, Jairath S, Nicholson BL (2001) Phylogenetic relationships of aquatic birnaviruses based on deduced amino acid sequences of genome segment A cDNA. Dis Aquat Organ 45:89-102

19. Nishizawa T, Kinoshita S, Yoshimizu M (2005) An approach for genogrouping of Japanese isolates of aquabirna viruses in a new genogroup, VII, based on the VP2/NS junction region. J Gen Virol 86:1973-1978

20. National Veterinary Institute of Finland (1985) Annual Report 1984: 76th Year of Operation. Valtion Painatuskeskus, Helsinki

21. Eriksson-Kallio AM, Holopainen R, Viljamaa-Dirks S, Vennerström P, Kuukka-Anttila H, Koski P, Gadd T (2016) Infectious pancreatic necrosis virus (IPNV) strain with genetic properties associated with low pathogenicity at Finnish fish farms. Dis Aquat Organ 118:21-30

22. Wolf K, Gravell M, Malsberger RG (1966) Lymphocystis virus: isolation and propagation in centrarchid fish cell lines. Science 151:1004-1005

23. Fijan N, Sulimanovic D, Bearzotti M, Muzinic D, Zwillingberg LO, Chilmonczyk S, Vautherot JF, de Kinkelin P (1983) Some properties of the Epithelioma papulosum cyprini (EPC) cell line from carp (Cyprinus carpio). Ann Virol (Inst Pasteur) 134:207-220

24. Orpetveit I, Mikalsen AB, Sindre H, Evensen O, Dannevig BH, Midtlyng PJ (2010) Detection of infectious pancreatic necrosis virus in subclinically infected Atlantic salmon by virus isolation in cell culture or real-time reverse transcription polymerase chain reaction: influence of sample preservation and storage. J Vet Diagn Invest 22:886-895

25. McColl KA, Davies KR, Young JG, Crane MSJ (2009) Aquatic birnavirus infections of finfish. In: Australian and New Zealand standard procedures. Sub-Committee on Animal Health Laboratory Standards

26. Bain N, Gregory A, Raynard RS (2008) Genetic analysis of infectious pancreatic necrosis virus from Scotland. J Fish Dis 31:37-47

27. Ullmann LS, de Camargo Tozato C, Malossi CD, da Cruz TF, Cavalcante RV, Kurissio JK, Cagnini DQ, Rodrigues MV, Biondo AW, Araujo JP (2015) Comparative clinical sample preparation of DNA and RNA viral nucleic acids for a commercial deep sequencing system (Illumina MiSeq $\left({ }^{\circledR}\right)$ ). J Virol Methods 220:60-63

28. Simpson JT, Wong K, Jackman SD, Schein JE, Jones SJ, Birol I (2009) ABySS: a parallel assembler for short read sequence data. Genome Res 19:1117-1123

29. Tamura K, Stecher G, Peterson D, Filipski A, Kumar S (2013) MEGA6: molecular evolutionary genetics analysis version 6.0. Mol Biol Evol 30:2725-2729

30. Lee J, Feldman AR, Delmas B, Paetzel M (2007) Crystal structure of the VP4 protease from infectious pancreatic necrosis virus reveals the acyl-enzyme complex for an intermolecular self-cleavage reaction. J Biol Chem 282:24928-24937

31. Imajoh $M$, Goto $T$, Oshima $S$ (2007) Characterization of cleavage sites and protease activity in the polyprotein precursor of Japanese marine Aquabirnavirus and expression analysis of generated proteins by a VP4 protease activity in four distinct cell lines. Arch Virol 152:1103-1114

32. Petit S, Lejal N, Huet JC, Delmas B (2000) Active residues and viral substrate cleavage sites of the protease of the birnavirus infectious pancreatic necrosis virus. J Virol 74:2057-2066

33. Kankainen M, Eskelinen U, Setälä J, Niukko J, Saarni K (2016) Kalankasvatuksen olosuhdekatsaus 2015. Natural Resources Institute Finland. http://urn.fi/URN:NBN:fi-fe2016112129501. Accessed 28 Mar 2017

34. Wei Y, Li J, Zheng J, Xu H, Li L, Yu L (2006) Genetic reassortment of infectious bursal disease virus in nature. Biochem Biophys Res Commun 350:277-287

35. Romero-Brey I, Bandín I, Cutrín JM, Vakharia VN, Dopazo CP (2009) Genetic analysis of aquabirnaviruses isolated from wild fish reveals occurrence of natural reassortment of infectious pancreatic necrosis virus. J Fish Dis 32:585-595

36. Heppell J, Tarrab E, Berthiaume L, Lecomte J, Arella M (1995) Characterization of the small open reading frame on genome segment A of infectious pancreatic necrosis virus. J Gen Virol 76(Pt 8):2091-2096

37. Hong JR, Gong HY, Wu JL (2002) IPNV VP5, a novel anti-apoptosis gene of the Bcl-2 family, regulates Mcl-1 and viral protein expression. Virology 295:217-229

38. Santi N, Song H, Vakharia VN, Evensen $\varnothing$ (2005) Infectious pancreatic necrosis virus VP5 is dispensable for virulence and persistence. J Virol 79:9206-9216

39. Mutoloki S, Jøssund TB, Ritchie G, Munang' andu HM, Evensen $\varnothing$ (2016) Infectious pancreatic necrosis virus causing clinical and subclinical infections in atlantic salmon have different genetic fingerprints. Front Microbiol 7:1393

40. Ruane NM, McCarthy LJ, Swords D, Henshilwood K (2009) Molecular differentiation of infectious pancreatic necrosis virus isolates from farmed and wild salmonids in Ireland. J Fish Dis 32:979-987

41. Song H, Santi N, Evensen O, Vakharia VN (2005) Molecular determinants of infectious pancreatic necrosis virus virulence and cell culture adaptation. J Virol 79:10289-10299

42. Tapia D, Eissler Y, Torres P, Jorquera E, Espinoza JC, Kuznar J (2015) Detection and phylogenetic analysis of infectious pancreatic necrosis virus in Chile. Dis Aquat Organ 116:173-184 
43. Ortega C, Rodríguez S, de las Heras AI, Romero A, Monrás M, Enríquez R (2011) Evaluation of the level of Mx3 protein synthesis induced by infectious pancreatic necrosis virus (IPNV) strains of different infectivity. Vet Immunol Immunopathol 141:190-200

44. Skjesol A, Skjæveland I, Elnæs M, Timmerhaus G, Fredriksen BN, Jørgensen SM, Krasnov A, Jørgensen JB (2011) IPNV with high and low virulence: host immune responses and viral mutations during infection. Virol J 8:396

45. Munro ES, Midtlyng PJ (2011) Infectious pancreatic necrosis and associated aquatic birnaviruses. In: Woo PTK, Bruno DW (eds) Fish diseases and disorders; viral, bacterial and fungal infections. CABI, Wallingford, pp 1-65

46. Gadan K, Sandtrø A, Marjara IS, Santi N, Munang'andu HM, Evensen $\varnothing$ (2013) Stress-induced reversion to virulence of infectious pancreatic necrosis virus in naïve fry of Atlantic salmon (Salmo salar L.). PLoS One 8:e54656

47. Dixon PF, Hill BJ (1983) Rapid detection of infectious pancreatic necrosis virus (IPNV) by the enzyme-linked immunosorbent assay (ELISA). J Gen Virol 64(Pt 2):321-330

48. Melby HP, Krogsrud J, Håstein T, Stenwig H (1991) All commercial Atlantic salmon seawater farms in Norway harbour carriers of infectious pancreatic necrosis virus (IPNV). In: Fryer JL (ed) Proceedings from the 2nd international symposium on viruses of lower vertebrates. Oregon State University, Corvallis, pp 211-217

49. Julin K, Johansen LH, Sommer AI, Jørgensen JB (2015) Persistent infections with infectious pancreatic necrosis virus (IPNV) of different virulence in Atlantic salmon, Salmo salar L. J Fish Dis 38:1005-1019

50. Ahne W, Thomsen I (1986) Infectious pancreatic necrosis: detection of virus and antibodies in rainbow trout IPNV-carrier (Salmo gairdneri). Zentralbl Veterinarmed B 33:552-554
51. Johansen LH, Sommer AI (1995) Multiplication of infectious pancreatic necrosis virus (IPNV) in head kidney and blood leucocytes isolated from Atlantic salmon, Salmo salar L. J Fish Dis $18: 147-156$

52. Tate H, Kodama H, Izawa H (1990) Immunosuppressive effect of infectious pancreatic necrosis virus on rainbow trout (Oncorhynchus mykiss). Nihon Juigaku Zasshi 52:931-937

53. Yamamoto $T$ (1975) Infectious pancreatic necrosis (IPN) virus carriers and antibody production in a population of rainbow trout (Salmo gairdneri). J Can Microbiol 21:1343-1347

54. Hedrick RP, Fryer JL (1982) Persistent infections of salmonid cell lines with infectious pancreatic necrosis virus (IPNV): a model for the carrier state in trout. Fish Pathol 16:163-172

55. Bootland LM, Dobos P, Stevenson RMW (1991) The IPNV carrier state and demonstration of vertical transmission in experimentally infected brook trout. Dis Aquat Org 10:13-21

56. Gregory A, Munro LA, Wallace IS, Bain N, Raynard RS (2007) Detection of infectious pancreatic necrosis virus (IPNV) from the environment in the vicinity of IPNV-infected Atlantic salmon farms in Scotland. J Fish Dis 30:621-630

57. Bruno DW (2004) Changes in prevalence of clinical infectious pancreatic necrosis among farmed Scottish Atlantic salmon, Salmo salar L. between 1990 and 2002. Aquaculture 235:13-26

58. Murray AG, Busby CD, Bruno DW (2003) Infectious pancreatic necrosis virus in Scottish Atlantic salmon farms, 1996-2001. Emerg Infect Dis 9:455-460 